\section{Jan Pešina}

Uniwersytet im. Adama Mickiewicza

w Poznaniu

jan.pesina@wp.pl

\title{
Tradycje religijne w czeskim dyskursie tożsamościowym okresu międzywojennego
}

\begin{abstract}
Pešina Jan, Tradycje religijne w czeskim dyskursie tożsamościowym okresu międzywojennego (Religious Traditions of the Czech Identity Discourse from the Interwar Period). "Poznańskie Studia Slawistyczne" 10. Poznań 2016. Publishing House of the Poznań Society for the Advancement of the Arts and Sciences, pp. 243-255. ISSN 2084-3011.

The main purpose of the article is to find the answer, how two different religious traditions (reformative and catholic) influenced the process of building of historical consciousness of secular Czech society in the interwar period. During the first years of the independent Czechoslovakia existence, a typical phenomenon was a domination of the hussite historical reminiscences, which culminated in the year 1925, during the national celebration of the 510 anniversary of Jan Hus' death. In the same time, it was possible to notice voices, which were questioning an asymmetric construction of historical consciousness and emphasizing necessity of 'extracting' also from other historical traditions. The opportunity to merge two main Czech spiritual traditions occured in the year 1929, when not only Catholic Church, but also Czechoslovak state organised Saint Wenceslas Millennium celebration. 'Over-confession' and 'over-ethnical' meaning of state parts of celebration should be considered as the successful change of unequal paradigm of historical consciousness, as well as the beginning of gradual process changing Czech society from the community defined in the ethnical-language way into civic society.
\end{abstract}

KeYwords: religious traditions; identity discourse; Czechoslovakia; Saint Wenceslas; Jan Hus

\author{
Vitězi, který vjǐždiš \\ do pražských bran \\ žehnej Ti svatý Václav \\ a Mistr Jan
}

(Karel Toman, Pozdrav TGM)

Wiersz Karla Tomana Pozdrav TGM, którego fragment wykorzystano jako motto niniejszego artykułu, został napisany w grudniu 1918 roku$^{1}$,

\footnotetext{
${ }^{1}$ W 1926 roku ukazał się w tomie wierszy Stoletý kalendář (Toman 1997).
} 
a zatem niedługo po powstaniu niepodległej Czechosłowacji. Wytycza on projekt połączenia dwóch rozbieżnych czeskich tradycji religijnych - świętowacławskiej i husyckiej. Międzywojenna Czechosłowacja, ze względu na swój demokratyczny oraz pluralistyczny charakter, budowała tożsamość na podstawie różnych źródeł, bazując przy tym na bardziej lub mniej żywych tradycjach nawiązujących do rozmaitych wydarzeń historycznych, o rodowodzie husycko-reformacyjnym i katolickim, zdefiniowanych nacjonalistycznie, jak i stanowiących pokłosie ponadetnicznego patriotyzmu terytorialnego (Med 2010: 114). W naszym artykule skupimy uwagę na dwóch tradycjach religijnych - świętowacławskiej (katolickiej) i husyckiej (reformacyjnej), które są głęboko zakorzenione w czeskiej historii $^{2}$. Przyjrzymy się temu, w jaki sposób były one uwzględniane w czeskim dyskursie tożsamościowym okresu międzywojennego, jak zostały wykorzystane w oficjalnej ideologii państwowej oraz czy rzeczywiście udało się te rozbieżne tradycje zjednoczyć, czy też pozostały one ze sobą sprzeczne.

\section{Nasz program to Tábor}

Świadomość historyczna społeczeństwa czeskiego pierwszych dwóch dekad XX wieku kształtowała się pod wpływem postaw antyklerykalnych większości czeskiej inteligencji przy równoczesnej dominacji reminiscencji husyckich ${ }^{3}$. Ze względu na to, że podczas pierwszej wojny światowej

${ }^{2}$ Kult św. Wacława jako patrona kraju zaczął się rozwijać w Czechach w drugiej połowie X wieku, osiągając szczyt w XIV wieku. W okresie kontrreformacji, w drugiej połowie XVII wieku, kiedy odczuwano zagrożenie rodzimej kultury, św. Wacław został także obrońcą narodu i języka. Początki tradycji husyckiej związane są z działalnością praskiego kaznodziei i reformatora Jana Husa z początku XV wieku. Ruch husycki, który rozwinął się w Czechach po śmierci Husa, uważany jest przez niektórych badaczy za prolog reformacji europejskiej.

${ }^{3}$ Ruch husycki jako centralne wydarzenie czeskiej historii naukowo „odkrył” w połowie XIX wieku František Palacký w nowoczesnej historiografii czeskiej Dějiny národu českého v Čechách a na Moravě (pierwsza część tomu dotyczącego husytyzmu ukazała się w 1850 roku), dokonując swoistej sekularyzacji średniowiecznego ruchu religijnego. Zaproponowaną przez niego interpretację husytyzmu jako ruchu demokratycznego oraz narodowo-emancypacyjnego spopularyzowali w drugiej połowie XIX wieku czescy publicyści i pisarze. Na pierwszym miejscu trzeba wymienić Aloisa Jiráska, który w swoim bogatym dorobku literackim poświęcił dużo miejsca ruchowi husyckiemu, zwłaszcza w trylogii Mezi proudy 
Kościół rzymskokatolicki zajął promonarchistyczną i prodynastyczną postawę, doszło w ogólnej opinii do umocnienia jego obrazu jako wroga narodowego. Dopiero nowa sytuacja społeczno-polityczna zaistniała po powstaniu Czechosłowacji 28 października 1918 roku stworzyła warunki do integracji rozbieżnych tradycji historycznych. Jednak atmosfera radykalizmu poprzewrotowego nie sprzyjała tym próbom, czego znanym przykładem jest zniszczenie w listopadzie 1918 roku przez tłum powracający z wiecu politycznego kolumny mariackiej na Rynku Staromiejskim jako rzekomego symbolu ucisku habsburskiego (Rak 1994: 45). Biograf i popularyzator (zdaniem badacza, Jiřego Raka, często raczej wulgaryzator) poglądów Tomáša G. Masaryka, Jan Herben, w broszurze agitacyjnej Bíla hora z 1920 roku $^{4}$ nie tylko akceptuje rozbieżność czeskich tradycji historycznych, ale je jeszcze uwypukla, stwierdzając, że istnieją dwa narody czeskie. Jeden naród reprezentują (w mniemaniu autora postępowi) przedstawiciele czeskiej reformacji, np. Jan Hus, Jan Žižka, Petr Chelčický, Jan Blahoslav lub Jan Amos Komenský, narodowi drugiemu przewodzą postacie „reakcyjne”: św. Wacław i św. Jan Nepomucen, cesarz Karol IV Luksemburg lub czescy katoliccy arystokraci: Vilém Slavata i Jaroslav Martinic (Rak 1994: 45).

Pierwsze lata istnienia niepodległej Czechosłowacji odznaczały się preferowaniem husyckiego modelu tożsamościowego: hasło „Tábor je náš program" ogłoszone przez Masaryka ${ }^{5}$ miało podkreślić republikański

(1897-1890), Proti všem (1893), Bratrstvo (1900-1909), tworząc paralelę literacką do naukowego dzieła Palackiego. W okresie międzywojennym powieści historyczne Jiráska wielokrotnie wznawiano.

${ }^{4}$ Trzechsetną rocznicę bitwy pod Białą Górą (8 listopada 1620 roku) można uznać za kulminację mitu białogórskiego. Krótka bitwa, która przesądziła o klęsce antyhabsburskiego powstania czeskich niekatolickich stanów, urosła w czeskiej świadomości historycznej XIX i początku XX wieku do rangi katastrofy narodowej. Klęskę białogórską uważano np. za bezpośrednią przyczynę germanizacji ziem czeskich, chociaż takie próby, umotywowane głównie względami praktycznymi, miały miejsce dopiero w ostatnich dekadach XVIII wieku.

${ }^{5}$ Masaryk zajmował się czeską reformacją, zwłaszcza postacią Jana Husa, już wcześniej, czego owocem była książka Jan Hus. Naše obrození a naše reformace wydana po raz pierwszy w 1896 roku. Dziedzictwo czeskiej reformacji potraktował jedynie jako punkt wyjścia do rozważań zajmujących się aktualnymi problemami społeczeństwa czeskiego. Przeszłość bowiem można, jego zdaniem, zrozumieć jedynie poprzez dialog z teraźniejszością: „Český člověk opravdový, český člověk myslící chce mít jednotný názor životní, chce míti přítomnost s minulostí organicky svázánu, chce míti obsah všeho svého snažení v souladu se 
charakter młodego państwa. Aktualizacja dziedzictwa husyckiego miała także swój wymiar konfesyjny w postaci założenia Kościoła czechosłowackiego (Církev československá) ${ }^{6}$, który został powołany do życia 10 stycznia 1920 roku.

Za kulminacyjny moment wykorzystania reminiscencji husyckich w oficjalnej ideologii państwowej uznać można okazałe obchody 510. rocznicy śmierci Jana Husa 6 lipca 1925 roku$^{7}$, które miały zrekompensować niemożliwość przeprowadzenia oficjalnych obchodów okrągłej rocznicy w czasie wojny i nad którymi patronat objął prezydent Masaryk. Uroczystości te stały się przyczyną dyplomatycznego konfliktu pomiędzy Czechosłowacją i Watykanem, znanego w literaturze jako afera Marmaggiego ${ }^{8}$. Protest Watykanu przeciwko państwowym obchodom rocznicy śmierci heretyka ${ }^{9}$ wywołał w Czechosłowacji odwrotny niż zamierzony skutek. Jeszcze w kolejną rocznicę śmierci Husa, w 1926 roku, podczas oficjalnego przemówienia prezydent Masaryk czuł potrzebę krytycznego nawiązania do wydarzeń sprzed roku, podkreślając pierwszorzędne znaczenie dziedzictwa husyckiego dla wspólnotowej świadomości narodu czeskiego: „Prohlašujeme, že není a nebude žádné síly nátlaku jakkoli mohutného, který by mohl zahladiti v nás slavnou památku Husovu, našeho mistra, největšího

základní ideou své historie, s Bratrstvím, s Humanitou, chce se spravovati tou ideou netoliko proto, že je česká, ale proto, že je správná, že jí nedovede odpírati” (Masaryk 1990: 43).

${ }^{6}$ Inicjatorami powstania niezależnego od Rzymu nowego Kościoła była grupa reformatorsko nastawionych czeskich księży katolickich, na czele których stał dr Karel Farský. Nowy Kościół (od 1971 roku noszący nazwę Církev československá husitská) nawiązywał do tradycji Kościołów reformowanych, wykazując tylko luźny związek z pierwotnym ruchem husyckim. Według spisu ludności z 1930 roku swoją przynależność do Kościoła czechosłowackiego deklarowało prawie 800 tysięcy wiernych (Kaňák 2007).

${ }^{7} 21$ marca 1925 roku czechosłowacki parlament przyjął ustawę, na mocy której dzień 6 lipca ogłoszono świętem narodowym.

${ }^{8}$ Ówczesny nuncjusz apostolski w Pradze, Francesco Marmaggi, w proteście przeciwko państwowemu charakterowi obchodów husowskich wyjechał z kraju, a Watykan zerwał w latach 1925-1928 stosunki dyplomatyczne z Czechosłowacją (Ehrenberger 2002: 23-27).

${ }^{9}$ Dopiero papież Jan Paweł II, podczas wizyty w Czechosłowacji w 1990 roku, odniósł się pozytywnie do osoby i dorobku Jana Husa, stwierdzając, że należy mu się ważne miejsce wśród reformatorów Kościoła. Punktem kulminacyjnym reinterpretacji działalności czeskiego kaznodziei w środowisku katolickim było Międzynarodowe sympozjum poświęcone Janowi Husowi, które odbyło się na Papieskim Uniwersytecie Laterańskim w Rzymie w 1999 roku (Pospíšil 2015: 88-89). 
hrdiny našeho národa, a prohlašujeme, že rázně a jednotně budeme hájiti jeho památku proti všem" (cyt. za: Ehrenberger 2002: 27).

Mniej więcej w tym samym czasie możemy jednak odnotować także krytyczną refleksję na temat dotychczasowej dominacji i upolitycznienia spuścizny husyckiej w ogólnej świadomości historycznej - i to nie tylko w publicystyce katolickiej (Jaroslav Durych ${ }^{10}$ ), ale także demokratycznej (Ferdinand Peroutka, Karel Čapek). Z krytyką bezwarunkowej idealizacji i aktualizowania tej spuścizny wystąpił również historyk Josef Pekař, podkreślając potrzebę oceny ruchu husyckiego wyłącznie w kontekście kultury późnego średniowiecza: „Závoj spadl s obrazu - a my vidíme ryzí středověk tam, kde jsme se domnívali viděti červánky novověku” (cyt. za: Rak 1994: 65) napisał w rocznicę śmierci Husa w 1925 roku.

Przyjrzyjmy się teraz bliżej tekstowi stanowiącemu przykład ówczesnego krytycznego spojrzenia na asymetryczny wymiar konstruowania czeskiej tożsamości historycznej i kulturowej. Wybitny dziennikarz okresu międzywojennego, Ferdinand Peroutka, wydał w 1924 roku książkę pt. Jací jsme. Jak autor pisze we wstępie, książka ta powinna być właściwie zatytułowana Jací nejsme, gdyż jej głównym celem jest wskazanie zbiorowych iluzji dotyczących czeskiego charakteru narodowego. Za źródło owych iluzji Peroutka uważa historyzm wciąż dominujący w czeskiej filozofii narodowej, będący dziedzictwem romantycznych wyobrażeń rodem z XIX wieku.

Z punktu widzenia omawianego problemu na szczególną uwagę zasługują te rozdziały książki, które podejmują polemikę z rozpowszechnionym wówczas w obiegowej opinii obrazem Czechów jako dziedziców spuścizny husycko-reformacyjnej, dla których katolicyzm stanowi obcą religię narzuconą rodzimej kulturze z zewnątrz. Zdaniem Peroutki (który w swoich wywodach historycznych opiera się zapewne m.in. na pracach naukowych Josefa Pekařa), to właśnie reformacja w wyniku rozwoju wypadków historycznych stała się w środowisku czeskim obcym i niezrozumiałym wtrętem, podczas gdy katolicyzm i kultura baroku wywarły istotny i niejako naturalny wpływ na kształtowanie nowoczesnego narodu czeskiego. W rozdziale Katolictví v Čechách Peroutka m.in. stwierdza:

${ }^{10}$ Aktywny udział pisarza i publicysty J. Durycha w czeskim sporze tożsamościowym okresu międzywojennego szczegółowo omawia Aleksandra Pająk. Cf. zwłaszcza rozdział: Katolicyzm Durycha odpowiedzią na pytanie o sens czeskich dziejów - publicystyka (Pająk 2006: 67-119). 
Naši lidé, postaveni tváří v tvár̆ husitství, byli by cítili neporozumění a zmatek a vedli by si stejně žalostně, jako pan Brouček ${ }^{11}$ na svém výletu do patnáctého století. Ale katolictví, které prosytilo celé naše prostředí, bylo jim čímsi blízkým a domácím. (...) Pokuste si odmyslit vliv katolictví z lidové písně, z lidového umění, ze zvyků, z př́isloví, z naší architektury, literatury, z pověstí a pohádek - jak velice bychom byli ochuzeni! Jak těžce by tím bylo zasaženo i to, co pokládáme za českou tradici. Kdekoliv se podíváme na dílo našeho lidu, at' slovné, at' zpěvné, barvové nebo tvarové, všude vidíme. že tu bylo katolictví silou oživující. (...) Velmi mnoho z toho, v čem vidíme typické vyjádření češství, přišlo do této země teprve z katolického kostela (Peroutka 1991: 56).

Paradoksalnie jednak, jak pisze Peroutka w innym miejscu, przeważający katolicki charakter dziewiętnastowiecznego społeczeństwa czeskiego nie przeszkadzał w rozwijaniu kultu krytyka Kościoła, Jana Husa. Było to możliwe, ponieważ w ogólnej świadomości obraz Husa uległ laicyzacji, a sam kaznodzieja był postrzegany przede wszystkim jako bojownik o czeską emancypację narodową:

Obyčejný český člověk, který tvoří národ, chápe velmi málo Husa jako náboženského myslitele a náboženský zjev, chápe-li ho vůbec v tomto smyslu. Pro něho je Hus jakási mlhavá představa, nějak souvisící s naším bojem proti Němcům a proti Vídni; Hus se mu hodí jako motto nad náš národní boj (Peroutka 1991: 54).

Polemikę z mitologizującym, oderwanym od realiów historycznych i w swoim wydźwięku antyhabsburskim oraz antykatolickim obrazem czeskiej przeszłości możemy znaleźć później także w twórczości innego czołowego reprezentanta demokratycznego (obywatelskiego) nurtu czeskiej publicystyki i literatury okresu międzywojennego, Karla Čapka, zwłaszcza zaś w jego satyrycznej, fantastyczno-naukowej powieści Inwazja jaszczurów, która wychodziła w odcinkach w dzienniku Lidové noviny w latach 1935-1936. W księdze drugiej, Po stupnich civilizace, która stanowi swoiste, na podstawie fikcyjnych wycinków z gazet odtworzone dzieje nowego gatunku inteligentnych płazów, możemy przeczytać felieton rzekomo autorstwa Jaromíra Seidla-Novoměstského Náš přitel na ostrovech Galapágos. Czeski turysta podczas podróży po wyspach Galapagos spotyka wykształconego płaza, który nie tylko zna język czeski, ale daje się poznać

${ }^{11}$ Chodzi o satyryczne opowiadanie Svatopluka Čecha Nový epochální výlet pana Broučka, tentokráte do XV. století (po raz pierwszy ukazało się w 1889 roku), które konfrontuje oportunizm czeskiego drobnomieszczanina XIX wieku z idealizmem epoki husyckiej. 
także jako znawca i miłośnik czeskiej historii. Jak się okazuje, źródłem jego wiedzy jest podręcznik Česky pro Mloky. Fragment dialogu podróżnika z uczonym jaszczurem, który pod wpływem lektury podręcznika przybrał imię Boleslav Jablonský, w satyrycznym ujęciu dezawuuje jeden z obiegowych mitów narodowych, a mianowicie mit białogórski:

„Vás tedy upoutaly i naše dějiny,“ zvolal jsem radostně. „Zajisté, pane“ odtušil Mlok. „Zejména pohroma bělohorská a třistaletá poroba. Četl jsem o nich velmi mnoho v této knize. Jste zajisté velmi hrdi na svou třistaletou porobu. Byla to veliká doba, pane.“ „Ano, těžká doba,“ přitakal jsem. „Doba útisku a hoře.“ „A úpěli jste?“" ptal se náš přítel s dychtivým zájmem. „Úpěli, trpíce nevýslovně pod jařmem sveřepých utiskovatelů.“ „To jsem rád,“ oddechl si Mlok. „V mé knize to právě tak stojí. Jsem velmi potěšen, že to jest pravda. (...) Bylo nám pohříchu loučiti se, nebot' lod' již dávala znamení k odjezdu. (...) Co byste, pane Jablonský, vzkázal našemu národu?“"Mlok se na chvilku zamyslil. „Řekněte svým krajanům,“ pravil posléze s hlubokým pohnutím, „řekněte jim... aby nepropadli staré slovanské nesvornosti... a aby chovali ve vděčné paměti Lipany a zejména Bílou horu! Nazdar, má poklona,“ skončil náhle, snaže se přemoci své city (Čapek 1981: 150-151).

Należy także zwrócić uwagę na retoryczne nacechowanie przytoczonego fragmentu. Autor nie tylko go celowo archaizuje na poziomie gramatycznym i leksykalnym, ale wykorzystuje także utarte sformułowania w rodzaju „doba útisku a hoře”, przy pomocy których w codziennej praktyce kształtowania świadomości historycznej wytwarzano zmitologizowany obraz przeszłości.

\section{Milenium świętowacławskie}

O ile tradycja husycka należała do repertuaru konstytutywnych składników kształtujących tożsamość historyczną społeczeństwa czeskiego od pierwszych lat istnienia niepodległego państwa, o tyle tradycja świętowacławska, mimo że gwarantująca „ciągłość w nieciągłości czeskiej historii” (Med 2010: 125), nie znalazła się wśród czynników historycznych współtworzących ideowe oblicze nowego państwa. Dopiero w drugiej połowie lat 20., w ustabilizowanej sytuacji demokratycznej codzienności, w ramach poszukiwania innych źródeł tożsamości historycznej doszło do rekapitulacji narodowych tradycji i mitów. Milenium świętowacławskie w 1929 roku stanowiło jeden ze szczytów takiej rekapitulacji, przy tej okazji bowiem 
zainicjowano szereg na szeroką skalę zakrojonych i płodnych dyskusji o tradycjach i mitach czechosłowackiej państwowości i tożsamości wspólnego państwa Czechów, Słowaków i Niemców (Med 2010: 125-126).

Oficjalne państwowe obchody milenium odbyły się w dniach 22-29 września 1929 roku pod patronatem Masaryka, który w uroczystym przemówieniu stwierdził, że: „i legenda může vyslovit ideály národa, a to je mně také historický fakt. (...) Život a smrt svatého Václava nás učí, že zdravý život národa spočívá na vzdělanosti a mravnosti, na mravnosti posvěcené pravou zbožností” (cyt. za: Med 2010: 126).

Obok oficjalnych obchodów milenium - państwowych i kościelnych tematyka świętowacławska odbiła się szerokim echem w czeskim życiu intelektualnym i literackim, co, zważywszy na jego przeważnie lewicowy charakter, należy uznać za swoisty fenomen. Oprócz Svatováclavskiego sbornika, w którym zaprezentowany został dorobek historiografii czeskiej w zakresie badań świętowacławskich, tematyka ta często też powracała w wypowiedziach publicystów pochodzących ze wszystkich (oprócz komunistycznego) środowisk politycznych. František X. Šalda, który w swych poglądach na tę tradycję zbliżał się pod pewnymi względami do lewicy, w 1929 roku polemizował w Zápisníku z tymi, którzy w imię postępu odrzucali duchowy (święty) wymiar osobowości księcia Wacława. Taki dylemat, tzn. próba odpowiedzi na pytanie, czy księcia Wacława należy czcić bardziej jako świętego patrona czy jako męża stanu, nie pojawił się w czeskim dyskursie tożsamościowym ani po raz pierwszy, ani po raz ostatni. Zdaniem Šaldy, nie należy, odrzucając świętość Wacława, zubażać jego obrazu, zwłaszcza że prawdziwa rewolucyjność i religijność, w opinii krytyka, wcale się nie wykluczają:

kníže je pojem z oblasti moci světské, hmotné, časné, kdežto světec je pojem z oblasti duchové a mravní. Jste-li ochotni uctívat knížete, jste na stanovisku mravně a duchovně nižším, než byste byli, kdybyste projevili ochotu, pokloniti se před světcem. (...) Revolučnost je pojem univerzálnosti právě jako katolicismus; pravá revolučnost je také náboženskost, která touží obejmouti a objímá vpravdě celý svět. Opravdový revolucionář revolucionizuje a rozšiřuje starou tradici, zakládá po případě tradici novou, právě revolucionářskou. Ale nevylučuje se nikdy z tradice, nestaví se nikdy mimo ni zatrpkle, zatuchle a neplodně (Šalda 1990: 317, 319).

W literaturze pięknej poświęcono tradycji świętowacławskiej szereg wierszy oraz kilka dramatów, którym przyjrzymy się bliżej w dalszej części 
artykułu. Kwintesencję refleksji poświęconej tematyce świętowacławskiej przedstawia jednak esej historyczny Josefa Pekařa Svatý Václav, uznany za jeden z najistotniejszych głosów w dyskusjach milenijnych. Tekst ten odegrał ważną rolę w późniejszej interpretacji tradycji świętowacławskiej, zwłaszcza w środowisku czeskich intelektualistów oraz publicystów katolickich (Med 2010: 126-128). Można powiedzieć, że to właśnie autorytet naukowy Pekařa (który zresztą omawianej tematyce poświęcił kilka prac już na początku XX wieku) wyznaczył główne ramy interpretacji dziedzictwa świętowacławskiego w milenijnym 1929 roku, przyczyniając się do integracji rozbieżnych tradycji. Na wstępie swojego eseju badacz stwierdza:

Tisícileté panování světce Václava znamenalo v naší minulosti nepoměrně více než několikaletá vláda knížete. Obojí dějství, to na zemi i ono na nebi, spolu ovšem souvisí, bez onoho by nebylo tohoto, Václava svatého od Václava knížete bez násilí děliti nelze - oba v jedno nerozlučně spojila víra křest’anská, jež z člověka vytvořila světce a dala mu moc žíti i po časné smrti a panovati dale svému národu. Bez porozumění logice a moci této náboženské víry není možná porozuměti významu a dějinné úloze sv. Václava, ale bez ní nebylo by lze porozuměti celým staletím našich dějin, zejména nikoliv husitství (Pekař 1990: 13).

Do istotnych głosów w dyskursie tożsamościowym, które towarzyszyły świeckiej części obchodów milenium, należały już wspomniane sztuki świętowacławskie. Tematyka ta nie była wówczas w dramacie czeskim nowa. Skomplikowane dzieje początków państwa czeskiego przyciągnęły już niejednokrotnie uwagę dramatopisarzy. Wypada w tym miejscu przypomnieć np. Krvavé křtiny aneb Drahomíra a její synové Josefa Kajetana Tyla (sztukę wystawianą zresztą w czeskich teatrach do dzisiaj) lub tragedię Bratři Jaroslava Vrchlickiego.

Z ważniejszych starszych sztuk świętowacławskich należy wskazać jeszcze neoklasycystyczny dramat Františka Langera Svatý Václav z 1912 roku. Dzieło to było cenione przez ówczesną krytykę przede wszystkim ze względu na klasyczną czystość formy, kunszt językowy i metrum (tekst jest pisany heksametrem), natomiast ideowemu przesłaniu sztuki nie poświęcano wiele uwagi. Zdaniem Zdeňka Hořínka niesłusznie jednak, gdyż Langer podjął ciekawą próbę stworzenia dramatycznego bohatera przy wykorzystaniu konfliktu wewnętrznego wynikającego z faktu, iż chrześcijański święty jest równocześnie świeckim władcą (Hořínek 1993: 22). 
Ciekawą propozycję interpretacyjną stanowi także sztuka Jaroslava Durycha Svatý Václav. Kvas na Boleslavi z 1925 roku, otwierająca nieco inną perspektywę przedstawienia historii bratobójstwa. Autor konsekwentnie przestrzega zasady jedności miejsca, czasu i akcji, toczącej się w grodzie Bolesława w ciągu jednej doby i skoncentrowanej wokół jednej sytuacji, w której krzyżują się wszystkie płaszczyzny religijnego, moralnego oraz politycznego konfliktu. Po jednej stronie sporu stoi monolityczny i konsekwentny Wacław, po drugiej zaś - wewnętrznie zróżnicowana grupa sprzymierzeńców Bolesława. To właśnie niejednoznacznego, zmiennego i wahającego się bratobójcę uczynił Durych głównym bohaterem swojej sztuki.

Od dwóch poprzednich dramatów znacznie różni się milenijna sztuka autorstwa Stanislava Loma Svatý Václav (uroczysta premiera odbyła się 28 września 1929 w Teatrze Narodowym). Komitet Świętowacławski, który zajmował się państwową częścią obchodów milenijnych, w tym także programem kulturalnym, pierwotnie zaproponował wystawienie sztuki na deskach Teatru Narodowego Jaroslavowi Durychowi. Ostatecznie jednak wybrano tekst Loma, zdaniem Komitetu bardziej odpowiadający zapotrzebowaniu na wypowiedź ogólnonarodową (czego postać i twórczość katolickiego autora Durycha nie mogła być gwarantem). Sam Jaroslav Durych, uważający zresztą, że obchody milenium nie mogą mieć charakteru powszechnego i uznający św. Wacława przede wszystkim za chrześcijańskiego rycerza, skomentował decyzję Komitetu z typową dla siebie ironią:

I bude tedy svatý Václav oslavován oficielně hrou Stanislava Loma, autora Převratu, Vůdce, Kající se Venuše aj. Moudré všenárodní a všelidské myšlenky proniknou do lidu za přitomnosti státních veličin a vzácných hostí. Náboženský socialismus se svou ušlechtilou úměrností, vyhovující potřebám státním a dnešním poměrům, vznešeně se včlení do oslav sv. Václava s úchvalou svatováclavského výboru (cf. Hořínek 1993: 20).

Stanislav Lom rzeczywiście napisał sztukę odpowiednią dla inscenizacji „,ogólnonarodowego spektaklu”. Ze względu na szerokie ujęcie czasowe jego tekst jest nie tylko dramatem o św. Wacławie, ale także ,tragiczną sztuką o czeskiej historii”, która w ośmiu aktach obejmuje historię od zamordowania księżnej Ludmiły aż do śmierci Wacława. Sztuka zawiera chyba wszystkie znane wątki dotyczące życia i śmierci księcia: pogańskie obrzędy księżnej Drahomiry, zabójstwo księżnej Ludmiły, konflikt 
pomiędzy Wacławem i Bolesławem na tle sporu o władzę, wojnę i pojednanie z Niemcami, pojedynek Wacława z buntowniczym księciem Radslavem Zlickim, wahanie się Bolesława, morderstwo Wacława i końcową apoteozę, podczas której bratobójca kaja się i z wyciągniętymi rękoma recytuje chorał świętowacławski (Hořínek 1993: 20).

Podobne do sztuki Loma przesłanie zawiera także pierwszy czechosłowacki film kostiumowy Svatý Václav w reżyserii Stanislava Kolára z 1929 roku. Dotowany przez państwo i z wielkim rozmachem zrealizowany obraz historyczny nie odcisnął jednak trwalszego śladu w ogólnej świadomości, do czego zapewne przyczynił się fakt, że pojawienie się w kinach filmu zrealizowanego techniką kina niemego nakładało się w czasie z pierwszymi projekcjami bardziej dla widza atrakcyjnych filmów dźwiękowych (Taussig 2009: 167-171).

Zdaniem Jířego Raka, próba zintegrowania rozbieżnych tradycji historycznych podjęta przez państwo czechosłowackie w 1929 roku nie spełniła oczekiwań: obchody milenijne, łącznie z akcjami kulturalnymi, odebrane zostały przez społeczeństwo przede wszystkim jako uroczystości kościelne. Trwały zysk, według Raka, milenium przyniosło historiografii czeskiej - ukazało się kilka tomów Svatováclavskiego sborníka ${ }^{12}$ z artykułami czołowych czeskich historyków, archeologów oraz historyków sztuki, które do dzisiaj tworzą podstawowe kompendium wiedzy na temat najstarszych dziejów państwa czeskiego (Rak 1994: 46).

Z tym poglądem nie można się do końca zgodzić. Śledząc rozwój wypadków historycznych w następnych kilku dekadach, można by rzeczywiście dojść do wniosku, że próba zintegrowania dwóch rozbieżnych tradycji historycznych skończyła się niepowodzeniem. Tradycja świętowacławska została w czasie okupacji nazistowskiej skompromitowana i zdegradowana ${ }^{13}$, następnie zaś - po przejęciu w 1948 roku władzy przez komunistów

${ }^{12}$ Poszczególne tomy ukazały się w latach 1934-1939.

${ }^{13}$ Po rozbiciu Czechosłowacji i powstaniu tzw. drugiej republiki jesienią 1938 roku doszło do zasadniczej reinterpretacji dziedzictwa świętowacławskiego na potrzeby nowego reżimu. Wczorajszy symbol ruchu oporu stał się przykładem realizmu politycznego, który każe uznać podporządkowaną pozycję Czech wobec Niemiec. Taka deheroizacja św. Wacła- 
- zmarginalizowana. Spuściznę zaś husycką w historiografii marksistowskiej ponownie podniesiono do rangi jednej z konstytutywnych czeskich tradycji przy zawoalowanym wykorzystaniu dziewiętnastowiecznych schematów historiozoficznych (Górny 2001). Z tego punktu widzenia rzeczywiście próba integracji z 1929 roku może się wydawać nieudana. Trudno jednak porównywać funkcjonowanie i rozwój tradycji historycznych (o rodowodzie religijnym) w demokratycznym państwie, jakim była międzywojenna Czechosłowacja, $\mathrm{z}$ ich kształtowaniem się w warunkach reżimów totalitarnych. Bardziej sensowne wydaje się spojrzenie na problem z krótszej perspektywy czasowej dwóch dekad okresu międzywojennego.

Kontrowersje, które towarzyszyły politycznie umotywowanej aktualizacji dziedzictwa husyckiego i których punktem kulminacyjnym był 1925 rok, uwidoczniły zapotrzebowanie na inne tradycje historyczne, do czego okazję stworzył właśnie milenijny rok 1929. Przejęcie patronatu nad obchodami milenium św. Wacława przez państwo czechosłowackie było umotywowane próbą pojednania z Kościołem katolickim, jak również miało podkreślić głębokie historyczne zakotwiczenie młodego państwa w dziejach Europy.

Cennego i - dostrzegalnego dopiero w dłuższej perspektywie czasowej - pozytywnego wkładu próby integracyjnej z 1929 roku należy szukać także w rozpoczęciu przemian, jakkolwiek były one w następujących kilku dekadach skutecznie hamowane, prowadzących do przekształcenia społeczeństwa zdefiniowanego nacjonalnie w stronę społeczeństwa obywatelskiego.

\section{Literatura}

Čapek K., 1981, Válka s Mloky, Praha.

Ehrenberger T., 2002, Husův svátek jako př́čina diplomatického konfliktu mezi Československem a Vatikánem, „Dějiny a současnost” nr 4, s. 23-27.

Górny M., 2001, Między Marksem a Palackým. Historiografia w komunistycznej Czechostowacji, Warszawa.

Gut K., Kapras J., Novák A., Stloukal K., (red.), 1934, Svatováclavský sborník I, Praha. Hořínek Z., 1993, Světec jako dramatický hrdina, „Divadelní revue” nr 4, s. 18-26.

wa doprowadziła do dewaluacji tradycji świetowacławskiej, czyniąc z niej oficjalny symbol konformizmu politycznego (Med 2010: 133). 
Kaňák B., 2007, Církev československá husitská. Stručná historie, <http://www.ccsh. cz/view.php?id=18>, 22.08.2015.

Masaryk T.G., 1990, Jan Hus. Naše obrození a naše reformace, Praha.

Med J., 2010, Literární život ve stínu Mnichova (1938-1939), Praha.

Pająk A., 2006, Jarosław Durych a spór o sens czeskich dziejów, Opole.

Pekař J., 1990, Svatý Václav, w: J. Pekař, Postavy a problémy českých dějin, Praha, s. $13-58$.

Peroutka F., 1991, Jací jsme, Praha.

Pospíšil C.V., 2015, Husovská dilemata, Kostelní Vydří.

Rak J., 1994, Bývali Čechové. České historické mýty a stereotypy, Jinočany.

Šalda F.X., 1990, Šaldi̊v zápisník I (1928-1929), Praha.

Taussig P., 2009, Český biják, Praha.

Toman K., 1997, Básně, Praha. 